口腔領域扁平上皮癌に対する TPP (THP-ADM, CDDP, PEP)

動注化学療法の試み

\author{
橋本賢二・鈴木浩之・北川善政・山口万枝 \\ 山田一郎・謝虢鋝・田代悦章・松下文彦 \\ 上田吉生・式守道夫・福田廣志
}

\title{
Combined intra-arterial chemotherapy with TPP (THP-ADM, CDDP, PEP) for oral squamous cell carcinomas
}

\author{
Kenji Hashimoto $\cdot$ Hiroyuki Suzuki $\cdot$ Yoshimasa Kitagawa \\ Kazue Yamaguchi $\cdot$ Ichiro Yamada $\cdot$ Kuo Jeng Hsieh \\ Etsuaki TASHIRO • Fumihiko Matsushita - Yoshio UedA \\ Michio ShIKImori • Hiroshi FukUda
}

\begin{abstract}
The authors designed a regimen of TPP intra-arterial chemotherapy (THP-ADM, CDDP and PEP) for the treatment of oral squamous cell carcinomas. Twenty-one patients were treated, and markedly effective results were obtained.

The regimen of TPP intra-arterial chemotherapy was $20 \mathrm{mg} / \mathrm{m}^{2}$ of THP-ADM on day 1 (one shot), $50 \mathrm{mg} / \mathrm{m}^{2}$ of CDDP continuous infusion on day 2, and $5 \mathrm{mg} / \mathrm{m}^{2}$ of PEP from days 3 to 7 . After 2 weeks of no treatment, the above regimen was repeated every three weeks. As a rule, 2 cycles were performed. One cycle was received by 3 cases, and 2 cycles were received by 18 cases.

The median age of the patients was 57.1 years old (15 males, 6 females).

Primary lesions involved the tongue in 8 cases, maxillary sinus and mandibular gingiva in 3 cases each, buccal mucosa and oral floor in 2 cases each, and the palate, oropharynx and mandibular central carcinoma in 1 case each.

TNM classification was Tis in 1 case, T2 in 7 cases, T3 in 1 case, and T4 in 12 cases. All cases were M0. The clinical response was CR in 6 cases (28.6\%), PR in 14 cases (66.7 $\%$ ), and $\mathrm{MR}$ in 1 case. The response rate was $95.2 \%$. Among the 8 cases of tongue carcinoma, 4 were $\mathrm{CR}(50 \%)$ and 4 were $\mathrm{PR}$ for a response rate of $100 \%$. The response to this chemotherapy of metastatic regions in 11 cases involving the submandibular and cervical lymph nodes was $\mathrm{CR}$ in 1 case and $\mathrm{PR}$ in 10 cases. The response rate of metastatic lymph nodes was therefore $100 \%$.

The main side effects were hair loss on the treated side in 20 cases (95.2\%), anorexia in 18 cases $(85.7 \%)$, stomatitis in 17 cases (80.9\%), nausea and vomiting in 11 cases (52.4 $\%$ ), facial flush in 10 cases $(47.6 \%)$, and fever in 7 cases $(33.3 \%)$.

Leukopenia $(57.1 \%)$ and thrombocythemia (23.8\%) were noted as laboratory abnormalities, but there were no severe cases.
\end{abstract}

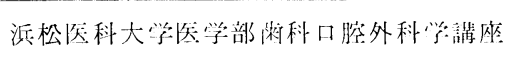

(主任: 槅本賢二教授)

Department of Dentistry and Oral and Maxillo- facial Surgery, Hamamatsu University School of Medicine (Chief: Prof. Kenji Hashimoto)

受付日：平成 4 年 12 月 20 日 
Key words: oral squamous cell carcinoma (口腔領域扁平上皮癌), intra-arterial chemotherapy (動注化学療法), TPP (THP-ADM, CDDP, PEP) therapy (TPP 療法)

緒

\section{$\overline{\overline{\bar{D}}}$}

口腔癌の治療は, 近年再建手術の進歩により根治的手 術が可能となり, 形態のみならず機能的再建が行えるよ らになってきたが, 治療開始時すでに進行癌や再発癌の 場合, 浸潤範囲が広く十分な切除や再建が困難なことが ある.

そこで, 術前照射や術前化学療法による stage down をはかり，根治切除を容易にする方法が検討されてい る. 口腔癌の術前化学療法として, 現在最も頻用されて いる Cisplatin (CDDP) を中心とした PP (CDDP+ PEP (peplomycin)) 療法に THP-ADM (Pirarubicin)

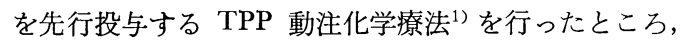
良好な成績を得たので報告する。

\section{対象と方法}

1990年 1 月より1992年 4 月までに当科で本療法を行っ た21例である（表 1). 性別では男性15名, 女性 6 名で, 年齢は 45 歳から 78 歳, 平均 57.1 歳であり, 原発部位別 では, 舌 8 例が最も多く, 上顎洞・下顎歯肉各 3 例, 煩 粘膜 - 口底各 2 例, 口蓋・口峡咽頭 -下顎骨中心性各 1 例であった. TNM 分類では, Tis：1例, T2: 7 例, $\mathrm{T} 3: 1$ 例, T4 : 12 例であり, N0 : 10 例, N1 : 8 例, $\mathrm{N} 2: 3$ 例で M は全例 M0 であった。病理組織学的診断 は，全例扁平上皮癌であった，投与回数は，1コースの み 3 例， 2 コース投与18例であった。

本療法の regimen は, Day 1 には浅側頭動脈より逆行 性に動注管を設置し，手術室にて THP-ADM (20 mg/ $\mathrm{m}^{2}$ )を one shot 動注する. Day 2 に hydration しながら CDDP $\left(50 \mathrm{mg} / \mathrm{m}^{2}\right)$ を 2 時間以上かけて動注, Day 3〜 7 に PEP $\left(5 \mathrm{mg} / \mathrm{m}^{2}\right)$ 持続動注 し, その後 2 週間休薬 する. 以上を 1 コースとし, 原則として 2 コース施行し た. 副作用防止薬は, 適宜使用した ${ }^{1)}$.

\section{結果}

\section{1. 治療成績}

臨床効果判定は, 頭頸部癌治療効果判定基準に準じ, 本療法終了後または後続治療直前に行った（表 2).

舌では 8 例中 CR 4 例, PR 4 例で CR 率 $50 \%$, 奏 効率 100\% であり, 上顎洞・下顎歯肉各 3 例もすべて PR で奏効率は，ともに $100 \%$ であった。下顎骨中心性 の 1 例は, 2 ュース終了後臨床的には判定不能であった が，画像診断で縮小傾向が認められ MR と判定した。
表 1 TPP 動注化学療法のまとめ

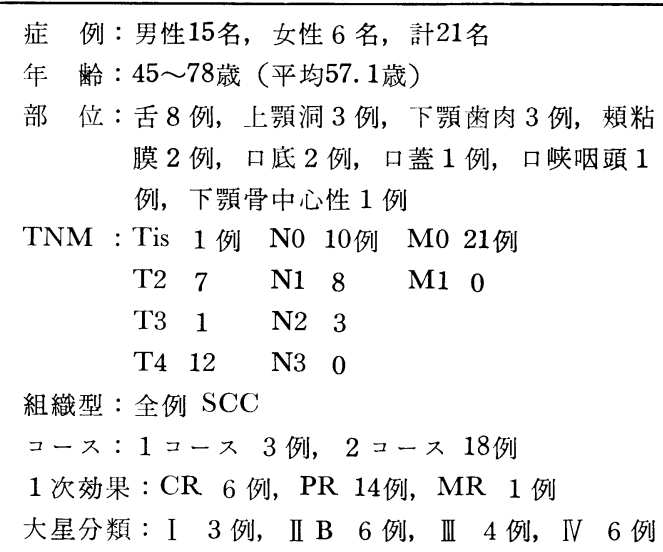

全21例では, CR： 6 例, PR：14例, MR：1例で奏効 率95.2\%であった。 また, 初診時 $\mathrm{N}(+)$ 群 11 例のリン パ節に対する効果は, CR：1 例, PR：10 例で奏効率 100\%であった.

\section{2. 副作用}

脱毛がほぼ全例にみられた。 その他食欲不振，悪心・ 嘔吐, 口内炎が高率にみられ, 顔面紅斑, 発熱が約 $1 / 3$ にみられた（表了）。しかし，難聴や心笳障害，呼吸器 症状などは認められなかった。

臨床検查值の異常は, 白血球減少が $57.1 \%$ その他血小 板減少, GOT・GPT 異常, CCr 低下などが認められ たが，いずれも後続治療に影響はなかった。

\section{3. 組織学的効果}

21例中外科療法を追加した16例と生検を行えた 3 例の 計19例について病理組織学的に効果判定した。 大星・下 里分類では, Grade I：3 例, Grade II B： 6 例, Grade III : 4 例, Grade IV : 6 例であり, Grade III 以上は 10/ $19(52.6 \%)$ であり, Grade II B 以上は16/19 (84.2\%) であった（表 1 ).

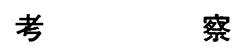

近年, 頭頸部癌に対する術前化学療法 (neo adjuvant chemotherapy）として CDDP を主体とした PP 療法と $\mathrm{CF}(\mathrm{CDDP}+5 \mathrm{FU})$ 療法が行われている.なかでも $\mathrm{PP}$ 療法特に PR 動注療法は有用な方法とされている2). 口 腔癌の化学療法検討会第 1 次研究の結果では, PP 静注 群 50例中 PR：25例で奏効率 50\%であり, PP 動注群23 例では, CR： 2 例, PR：17例で奏効率は $82.6 \%$ 之高い ものの, ともに CR 率は $0 \%, 8.7 \%$ と低 ${ }^{3)}$, 術前化 
表 2 TPP 動注化学療法の効果

\begin{tabular}{|c|c|c|c|c|c|c|c|}
\hline \multirow{2}{*}{ 部 位 } & \multirow{2}{*}{ 例数 } & \multicolumn{5}{|c|}{ 臨床効果（リンパ節） } & \multirow{2}{*}{$\begin{array}{l}\text { 奏効率\% } \\
\mathrm{CR}+\mathrm{PR}\end{array}$} \\
\hline & & CR & PR & MR & $\mathrm{NC}$ & $\mathrm{PD}$ & \\
\hline \multirow{3}{*}{$\begin{array}{l}\text { 舌 } \\
\text { 上顎 洞 } \\
\text { 下顎蒌肉 }\end{array}$} & 8 & 4 & \multirow{8}{*}{$\begin{array}{l}4(2) \\
3(2) \\
3(2) \\
1(2) \\
2(2)\end{array}$} & \multirow{8}{*}{1} & & & $100 \%$ \\
\hline & 3 & \multirow{7}{*}{$\begin{array}{ll} & 1 \\
& \\
& \\
1 & \end{array}$} & & & & & 100 \\
\hline & 3 & & & & & & 100 \\
\hline \multirow{4}{*}{$\begin{array}{l}\text { 口 底 } \\
\text { 煩 粘 膜 } \\
\text { 下顎骨中心性 } \\
\text { 口峡咽頭 }\end{array}$} & 2 & & & & & & 100 \\
\hline & 2 & & & & & & 100 \\
\hline & 1 & & & & & & 0 \\
\hline & 1 & & & & & & 100 \\
\hline 口蓋 & 1 & & & & & & 100 \\
\hline & 21 & $6(1)$ & $14(10)$ & 1 & & & $\begin{array}{c}95.2 \\
(100)\end{array}$ \\
\hline
\end{tabular}

表 3 副作用と検査値異常

\begin{tabular}{lr}
\hline 副作 用 & TPP $(\mathrm{n}=21)$ \\
\hline 脱 毛 & $20(95.2 \%)$ \\
口内 炎 & $17(80.9 \%)$ \\
悪心, 嘔吐 & $11(52.4 \%)$ \\
食欲不振 & $18(85.7 \%)$ \\
顔面紅斑 & $10(47.6 \%)$ \\
発 熱 & $7(33.3 \%)$ \\
\hline 臨床㭘査值異常 & \\
\hline 白血球隇少 & $12(57.1 \%)$ \\
血小板滅少 & $5(23.8 \%)$ \\
GOT & $5(23.8 \%)$ \\
GPT & $6(28.6 \%)$ \\
\hline
\end{tabular}

学療法としても今一つ切れ味が悪く, われわれは, PP $+\alpha$ 療法を検討してきた. ADM (Adriamycin) はアン スラサイクリン類の抗腫瘍性抗生物質で, 悪性リンパ腫 や骨肉腫などに有効な薬剂で, 最近癌腫にも多剂併用療 法で用いられているが副作用として心筋障害があり，使 用上の制約を受けていた，近年，この ADM の心笳障 害の発現を抑え，抗腫瘍効果は同等である THP-ADM が開発された。 今回 PP 療法に THP-ADM を加えた TPP 動注化学療法を行ったところ, 良好な成績を得た. 従来の報告で CDDP と PEP は, CDDP 先行の方が, CDDP と ADM では ADM 先行の方が有効率が高い とされて拈り，THP-ADM も同様と考え先行投与とし たが，THP-ADM の one shot 動注に関しては, 本療 法開始時には根拠はなかったが, その後日本化薬の研究 でマウス colon 38 で, THP-ADM の bolus 投与と 2 時間の infusion との比較で bolus 投与の方が有効があ
ることが判り，本法の妥当性を裏付ける結果となった.

TPP 療法に関して細田 ${ }^{4)}$ は, Ehrlich 腹水癌に対する THP-ADM と PP の併用効果について検討し,「その 併用効果は, THP-ADM による G2 block がピーク時 に CDDP を投与することにより，G2 block は増強さ れ, 同時に殺細胞作用により細胞は死滅の方向に導かれ る.ここで生き残った細胞は， G2-M 期の細胞に殺細胞 効果の高いPEP を，追い打ちをかけるように投与する ことにより，短時間にほとんど死堿させられたものと考 えられる」とし，頭頸部癌に対する TPP 療法の臨床的 有用性を指摘している.

臨床的には, 越智ら ${ }^{5)}$ は, Day 1 に CDDP $120 \mathrm{mg} /$ $\mathrm{m}^{2}$, PEP $15 \mathrm{mg} / \mathrm{m}^{2}$, ADM $30 \mathrm{mg} / \mathrm{m}^{2}$ をセルジンガー 法による超選択的局所動注療法で約10分間で投与し，頭 頸部悪性腫瘍20例中 CR 8 例 $(40 \%)$, PR 9 例で奏効 率は85\%であったとし，静注法 (Day 1 に CDDP 100 $\mathrm{mg} / \mathrm{m}^{2}$, ADM $30 \mathrm{mg} / \mathrm{m}^{2}$, Day 2 6 飞 PEP $10 \mathrm{mg} /$ $\left.\mathrm{m}^{2}\right) 23$ 例では, CR 7 例 $(30.4 \%), \mathrm{PR} 9$ 例で奏効率 は69.6\%であったと報告している。

浅井ら ${ }^{6)}$ は, Day 1 に THP-ADM $40 \mathrm{mg} / \mathrm{m}^{2}$, Day 2 に CDDP $70 \mathrm{mg} / \mathrm{m}^{2}$, Day $3 \sim 6$ に PEP $5 \mathrm{mg} /$ body を 静注する PTP 療法を, 頭頸部扁平上皮癌 9 例に行い, CR：1 例, PR： 8 例で奏効率 100\% であったと報告し ている.

今回, 口腔領域扁平上皮癌 21 例に本療法を施行し, CR : 6 例 $(28.6 \%), \mathrm{PR}: 14$ 例, MR：1例で奏効率 $95.2 \%$ の成績を得たが, 越智ら, 浅井らの報告と比べる と原発部位や stage，投与薬剂，投与量，投与方法など が異なるものの, PP+ADM も PP+THP-ADM も PP 療法に比べ高い $\mathrm{CR}$ 率, 奏効率を示して物り，特に THP-ADM 先行の TPP 療法は非常に高い奏効率であ った.

また, $\mathrm{N}(+)$ 症例のリンパ節に対する 1 次効果も奏効 
率 100\%であった，転移リンパ節に対する臨床効果の報 告は少なく, 佐藤ら゙) は, PP 静注 (CDDP 80〜160 $\mathrm{mg}$, PEP 10 15 mg 2 回/週 または隔日投与計 $20 \sim 90$ $\mathrm{mg}$ 点滴静注）した頭頸部扁平上皮癌 35 例中, 転移リン 八節に対する効果は CR：4 例 $(11 \%), \mathrm{PR}: 16$ 例で奏 効率57\%で, 転移リンパ節に対する臨床効果と原発巣に 対する治療効果は，ほ汴相関していたと述べ，固定性の 転移リンパ節に可動性が認められるようになり頸部郭清 術が容易になった症例があったことから，固定性転移り ンパ節に対し, 術前 PP 療法を試みる意義を指摘してい る. 今回初診時 $\mathrm{N}(+) 11$ 例のうち, $\mathrm{CR}: 1$ 例, $\mathrm{PR}$ : 10例でいずれのリンパ節も縮小し， T4N2 の固着リンパ 節症例で原発巣も転移リンパ節もともにPR を示したこ とから，本療法は原発巣のみならず転移リンパ節に対す る臨床効果も相関すると考えられ， stage downを計る 術前化学療法としての意義は大きいと考えている，本療 法終了後の病理組織学的効果判定は, 大星・下里分類で Grade III 以上が $52.6 \%$, Grade II B 以上は $84.7 \%$ と高 い奏効率を示して㔚り，臨床的効果と相関していた ${ }^{88}$. 副作用に関して, 越智らは PP-ADM 動注法で嘔気・ 嘔吐が $80 \%$, 貧血 $45 \%$, 白血球減少 $75 \%$ ，血小板減少 $25 \%$, 腎機能障害 $10 \%$, 脱毛 $65 \%$, 聴器障害は動注法に おいて高率であったと報告し, 浅井らは PTP 静注で一 過性の悪心・嘔吐・軽度の腎機能障害, 軽度の白血球減 少，脱毛などが認められたが，いずれも Grade 1〜2 でで，治療間隔の遅れもなく，後続治療も予定ど扣り可 能であったと報告している.

本報告では, 動注側の脱毛はほぼ必発で, 動注投与の ための局所濃度が高いためと考えられた。その他の副作 用は，十分な hydration や副作用軽減薬の適切な使用に より重篤にならず，後続治療を行えた。これは越智ら， 浅井らに比べ，薬剤投与量が少ないことが大きな原因で あると思われた。

また，本療法は効果発現が早く, Day 2 の CDDP 投 与時または Day 3 の PEP 投与時に, 腫瘍の縮小傾向 や腫瘍表面の平坦化などが認められることが多く，Day 7 には大部分が PR となった。 1 コースで有効と判定さ れたらち 3 例は, 後続治療に移行した. 今回は, NC, PD はなかったが 1 コースの投薬終了時点で効果の認められ ないものは後続治療に移行すべきだと考えている.

以上のことより，本療法は頭頸部扁平上皮癌に対する 術前化学療法として有用な方法と思われた。 今後症例を 増やし CR 期間, 再発・生存率などに関し検討したいと 考えている. 多くの施設で追試され，ご批判頂ければ幸 いである。
結

語

口腔領域扁平上皮癌 21 例飞対 ᄂ, THP-ADM 先行 TPP (THP-ADM, CDDP, PEP) 動注化学療法を行い, CR：6 例, PR：14例で, CR 率 $28.6 \%$, 奏効率 $95.2 \%$ の成績であった，初診時 $\mathrm{N}(+)$ 11例に対してもすべて に有効であった。副作用には，重篤なものはみられなか った。

本論文の要旨は, 第45回日本口腔科学会総会（1991年 5 月16日京都), 第 15 回日本頭頸部腫瘍学会 (1991 年 6 月28日東京), 第 46 回日本口腔科学会総会：ワークショ ップ (1992 年: 4 月 17 日名古屋), International Association for Maxillo-Facial Surgery 1992 Symposium (1992 作 9 月10日 Seattle）で口演発表した。

\section{引用 文 献}

1）橋本賢二, 铪木浩之, 他：口腔癌に対する TPP (THP-ADM, CDDP, PEP) 動注化学療法の検 討 (第 1 報) -1 次効果について一。基礎と臨 床 25：2593-2597 1991 .

2) 藤内 祝, 水谷英樹, 他 : 口腔, 頭頸部癌汇対 するCisplatin を主体とした化学療法, 第 2 報： PP 療法の静注法と動注法との制癌 1 次効果と 副作用の検討。口科誌 37：194-203 1988.

3) 橋本賢二, 塩田重利：口腔癌飞対する PP (CD $\mathrm{DP}, \mathrm{PEP})+\alpha$ 療法の検討 多施設共同研究 第 1 報 1 次研究結果（抄). 第 10 回日本口腔 腫瘍学会総会抄録集：47 1992 .

4) 細田兵之助: Ehrlich 腹水癌飞対する $4^{\prime}-\mathrm{O}$ tetrahydropyranyladriamycin, Cisplatin, Peplomycin による併用効果の検討。慶應医学 63： 635-644 1986.

5）越智健太郎, 大西純夫, 他: CDDP-PEP-ADM に上る頙頸部覀性腫瘍の治療成績。耳鼻臨林 82: 709-714 1989.

6) 浅井昌大, 菅澤 正, 他：頭頸部扁平上皮癌に 対する CDDP-THP-PEP 併用療法 (PTP 療法) の試み。癌の臨床 37：716-720 1991.

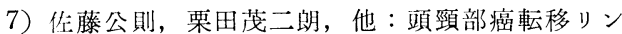
只節に対するシスプラチン・ペプロマイシン併 用療法の效果一臨床效果と組織效果一。日耳鼻 92: 535-541 1989.

8）鈴木浩之，橋本賢二，他：口腔癌に対する TPP 動注化学療法の組織学的評価（抄）。第 37 回日 本门腔外科学会総会抄録集：169 1992. 